\title{
THE LIBERAL PEACE: CHALLENGES TO DEVELOPMENT, DEMOCRACY AND SOFT POWER
}

\author{
Syed Mansoob Murshed \\ International Institute of Social Studies (ISS), Erasmus University of Rotterdam \\ PO Box 29776 \\ 2502 LT, The Hague, The Netherlands \\ Faculty of Business and Law \\ Coventry University \\ William Morris Building, Gosford Street, Coventry CV1 5FB, UK \\ Murshed@iss.nl
}

\begin{abstract}
The term liberal peace is employed to explain the absence of fatal conflict between democratic nations that are also economically interdependent. The expression, liberal peace, therefore, has an economic dimension, as well as an element based on a common polity and sets of values. I sketch the ideal and economic versions of the liberal peace theory. Policies promoting globalization may engender a backlash social conflict risks, as they produce inequality. In developed countries we witness the rise of populism, and the rolling back of the liberal aspects of democracy in developing countries. The avoidance of these problems require careful management of policies such that growth is broad-based, and policies promoting greater openness are sufficiently cushioned to protect losers. It is also necessary to manage globalization, and limit its negative impact on domestic social contracts, particularly when it comes to inequality, labour rights and fiscal austerity.
\end{abstract}

\section{Word Count: 8937}




\section{Introduction}

Nearly two centuries ago, Richard Cobden (1835) stated that 'Commerce is the grand panacea'. By this he meant both the pacific and civilizing effects of international trade and its role in assuaging tensions between nations. In contemporary political science the term liberal peace is employed to explain the absence of fatal conflict between democratic nations that are also economically interdependent. The expression, liberal peace, therefore, has an economic dimension, as well as an element based on a common polity and sets of values. Ultimately, these two strands of the liberal peace are inseparably linked; the literature on the liberal peace, however, may be dichotomised into ideal and economic tendencies. The ideal theory can be traced to Immanuel Kant's notions of foedus pacificum (league of peace) in his essay on the Perpetual Peace (1795), where the simultaneous adoption of a republican constitution generates a cosmopolitan peace. Its modern counterpart is to be found in the contemporary philosopher, John Rawls' (1999), thought. I discuss these theories briefly in section 2. Economic theories of the liberal peace probably originate in some of Montesquieu's ideas (1748) about the pacific benefits of commerce between peoples; a review of contemporary thinking can be found in Gartzke (2007), where it is labelled the 'capitalist' peace. ${ }^{1}$ I survey these theories in section 3.

Gleditsch (2008) has outlined a liberal 'tripod' where common democratic values, economic inter-dependence and the common membership of international organisations together buttress the 'liberal' peace. The term 'liberal' internationalist should be underscored in this regard, to distinguish this school of thought from 'realist' strands in political science and international relations, or for that matter neoconservative thinking which also stresses the joint merits of market capitalism and democracy.

While it is an empirical fact that advanced industrialized democracies do not go to war with another, this does not mean that democracies do not engage in wars. For example, according to the Human Security Report (2005), the UK has been involved in the greatest number of inter-state wars (21) during the 1946-2003 period ahead of France (19) and the USA (16). The Human Security Report also reports the total incidence of (internal as well as inter-state) conflict in different countries. In terms of 
the total number of conflict years, bearing in mind that there may be more than one civil war inside a single nation-state, which leads to more than one conflict in a single calendar year, the list is led by Burma with 232 conflict years since 1946. India follows with 156 years, and the UK with 77 years is in sixth position just behind Israel (79 years). This suggests that democracies like India, Israel and the UK are highly prone to war.

The accelerated pace of globalisation since about 1980 has been accompanied by growing inequality, particularly within nation states, although the inequality between countries may have decreased due to rising average incomes in China and India. I address these issues in section 4. This rise in inequality, when unaccompanied by a rise in social protection, has of necessity produced an increase in social tensions. One symptom of these tensions is the growth of illiberal political tendencies. In developed countries it manifests itself in mainly right-wing populism ${ }^{2}$, and in developing countries by the increasing authoritarianism on the part of elected governments, as I outline in section 5. Finally, section 6 concludes with some speculation on the way forward.

\section{Ideal Theories of the Liberal Peace ${ }^{3}$}

As indicated, ideal theories of the liberal peace can be traced back to the work of Immanuel Kant, who in his essay on the Perpetual Peace (1795) argues that although war is the natural state of $\operatorname{man}^{4}$, peace can be established through deliberate design. This requires the adoption of a republican constitution simultaneously by all nations, which inter alia would check the war-like tendencies of monarchs and the citizenry; the resultant cosmopolitanism that would emerge among the comity of nations would preclude war. $^{5}$

Kant's (1795) essay on the 'Perpetual Peace' provides us with information about the nature of the republican constitution that is of relevance to present day developing countries. First, observe the usage of the expression 'perpetual', implying permanence as opposed to a transient truce. In the contemporary parlance of game theory, such agreements or contracts would be described as re-negotiation proof or self-enforcing, so that there are no incentives to violate the stipulations of the league of peace. 
Secondly, and most crucially, Kant refers to the separation of powers between the executive and legislature (this ensures their proper and efficient functioning); we may also add the independence of the judiciary. Put simply, this concept implies good government that holds the domestic social contract together. Our contemporary understanding of good governance can include a host of other factors beyond the separation of powers, such as decentralized decision making powers. Thirdly, the stability of the peace depends upon the source of sovereignty or legitimate power within the nation. Although like all classical liberals Kant was not in favour of majoritarian democracy based on universal suffrage, he nevertheless points out that good governance provided by a dictator or an absolute monarch is inherently unstable as he or his successors face temptations to deviate from good government, and the assurance of good governance is more forthcoming in a system of power that is representative of the people. Central to the Kantian republican constitution is a system of checks and balances or a separation of powers which are largely absent from the fledgling democracies that characterise the developing world at present.

Interestingly, Kant (1795) argued that this cosmopolitan peace between nations might exclude distant lands, and aggressive wars, such as those associated with colonialism, might be waged against peoples deemed to be outside the pale of civilization. A similar point has recently been made by Gartzke (2007) in a different context where development and common goals precludes wars between countries at a similar level of development, but makes wars with distant countries at a lower level of development more likely.

Mirroring Kant's thoughts, is the contemporary philosopher, John Rawl's (1999) notion of peace between liberal societies, which he refers to as peoples and not states. Rawls' Law of Peoples is inspired by Kant's foedus pacificum and is termed a 'realistic utopia'. There is an appeal to both natural law and the possible implementation of an ideal morality. An ideal state is reasonable, even if in an imperfect world it is rational to deviate from such optima. He speaks of well ordered peoples. These are mainly constitutional liberal democracies, which arrive at such a polity based on an idea of public reason. Public reason encompasses the realm of the political, and is not necessarily part of any comprehensive doctrine that individuals may believe in (for example a religion like Judaism, Christianity or Islam or a secular 
belief such as Marxism), although some of these comprehensive beliefs may be compatible with a publicly reasoned well ordered society. In a well ordered society based on public reason human rights are respected, and the distribution of primary goods (a decent living standard, dignity, respect and the ability to participate) for each citizen's functioning are acceptably arranged. Above all, the principle of reciprocity characterises the determination and functioning of public reason and its workings as a constitutional liberal democracy. This implies both tolerance of difference, and respect for all other citizens.

It is worthwhile elaborating on Rawls' idea of well ordered peoples because the Law of Peoples extends the domestic social contract based on the criterion outlined above to a relation between peoples who reside in different nations. First, there are the liberal peoples described above. Secondly, there are decent peoples who have consultative hierarchies and associational organisations. Presumably, these are more conservative and less 'democratic' societies. But they respect human rights and have a reasonably equitable distribution of primary goods making them well ordered peoples. Thirdly, there are benevolent absolutisms; they respect human rights but because they lack decent consultative structures they cannot be considered well ordered. Fourthly, there are those societies that are burdened by unfavourable conditions which prevent the realisation of a well ordered decent outcome with human rights for all. Clearly, much of the developing world falls into this category. Finally, there is what Rawls' describes as outlaw states. These countries deliberately violate human rights. Furthermore, they may behave aggressively towards others; even coveting their resources.

The consequence of being a liberal state explains the empirically observed fact that 'true' democracies do not fight each other. It is also possible that a law of peoples, replicating a perpetual (sustainable) peace, exists between the first two categories of liberal and decent peoples, and might even extend to benevolent absolutisms. To the peoples who are burdened by unfavourable circumstances, others have a duty of assistance according to Rawls, but not one that results in outcomes completely eliminating international inequality. When outlaw states behave aggressively towards others, a just war with them is justifiable, provided that the universally accepted code of conduct for wars (the Geneva Convention, for example) is respected. 
Rawls argues that liberal societies do not go to war with each other because their needs are satisfied, they are non-acquisitive in the sense of not wishing to grow beyond an achieved steady-state level of (presumably high) income, and they are tolerant of difference. They will only fight in self-defence, and invade to prevent gross human rights abuses such as genocide in other countries. Democracies may, however, be driven by greed and the lust for power to wage war against other smaller non-democracies, as during the colonial period, the cold war era and even during the present-day war on terror. ${ }^{6}$

As far as the implications for developing countries are concerned, first the duty of assistance might extend to the principle of military intervention in countries burdened by unfavourable circumstances. For example, there is an increasing belief favouring Western military intervention to end certain long-standing civil wars (Collier, 2007). Secondly, developing countries facing economic stagnation may find themselves traversing down a path that takes them from being liberal or decent peoples to even outlaw states. Finally, economic decline may give rise to illiberal tendencies towards certain groups within a country; the nation itself may be characterised by factions not extending the principle of reciprocity towards each other, thus eventually falling into violent conflict.

\section{Economic Theories of the Liberal Peace}

Nation states have long been regarded to exist in a state of non-contractual anarchy vis-à-vis each other, making the exercise of power or the gathering of power by going to war an opportunistic act. Yet there are notions that a common set of values, and/or inter-state commerce will moderate or eliminate these war-like tendencies; see Doyle (1986), for example.

The liberal view that trade between nations directly contributes to peace can be traced back to the Baron de Montesquieu's, Spirit of the Laws (1748), where he states that commerce tends to promote peace between nations; mutual self-interest precludes war; trade also softens attitudes of peoples towards each other. The fact that commerce promotes peace was also pointed out by Tom Paine (1791-2, page 
265). Similar views were aired more strongly by Richard Cobden (1835). Sir Normal Angell (1910) asserted that nations could never enrich themselves through war, and even a victorious nation would come off economically worse from a war. Angell's (1910) view about the irrationality of war between the great powers of Europe in 1910 was based on a universal notion of rationality; bounded or limited rationality can never rule out wars, especially in the presence of misperceptions such as an exaggerated view of the probability of victory. It has to be remembered that trade is just one (peaceful) means of economically benefiting from the endowments of another country. The other means is war, representing the forceful acquisition of another country's resources - the mercantilist wars of $17^{\text {th }}$ century and the various colonial wars of conquest from the $16^{\text {th }}-19^{\text {th }}$ centuries offer numerous examples of these.

Polachek (1997) made the case for the purest form of the economic liberal peace, arguing that a common polity (democracy) is largely immaterial. He presents empirical evidence to suggest that advanced democracies cooperate, not because of their similar political systems, but due to their vast and multiply intersecting economic inter-dependence. War disrupts these networks, and is therefore against the interests of the nation states who are thus connected.

The trouble with the pacific interpretation of international trade is that during the two world wars of the $20^{\text {th }}$ century, highly interdependent economies went to total war with each other. Consequently, the economic inter-dependence argument for peace needs re-examination. Hegre (2000) argued that economic inter-dependence reinforces peace, but mainly between more developed economies. Russet and Oneal (2001) point out that it is the economic dependence on trade of the least dependent on the other member of a group of nations that will determine the pacific effect of trade. In short, only advanced and highly economically inter-dependent democracies would be at peace with one another, which precludes most developing countries, even if they are democracies like India.

Among the updates proposed for the liberal peace theory based on economic interdependence is the 'capitalist' peace notion of Gartzke (2007). He argues that the intensity of trade is the least important feature in the peace engendered by capitalism. 
The nature of advanced capitalism makes territorial disputes, which are mainly contests over resources, less likely as the market mechanism allows easier access to resources. The nature of production makes the output of more sophisticated goods and services increasingly reliant on 'ideas' that are research and development intensive, and skilled personnel can be acquired through more open global labour markets. Moreover, the disruption to integrated financial markets makes war less likely between countries caught up in that web of inter-dependence. We are all acutely aware of how disruptive financial crises and the resultant contagion that spreads all over the world are. ${ }^{7}$ Gartzke (2007) argues that common foreign policy goals reflected in the membership of international treaty organisations (NATO, the European Union etc.) also produces peace.

Dorussen and Ward (2010) rehabilitate the role of trade in engendering peace. They argue that trade has important indirect effects over and above the inter-dependence induced by bilateral trade. Increased trade generally, may do little to mollify war-like tendencies between a pair of countries, but if each of these countries interacts considerably with third countries, it will be not in their interests to go to war with each other, as it disrupts other links and networks. In other words, any two countries are unlikely to go to war with each other if there trade with the rest of the world is substantial even when their bilateral trade dependence is low. Murshed and Mamoon (2010) find evidence of this in their study of the effects of trade and democracy on India-Pakistan conflict. India and Pakistan are not only hostile towards each other, but their bilateral trade is very low compared to what would be predicted by their close proximity. Trade with the rest of the world has the greatest conflict reducing effect; however, the bilateral trade between these two countries is impeded by conflict, just as the limited value of trade is conflict enhancing.

This modern view of the liberal peace can be summarized as asserting that similar, contiguous democracies at a high level of economic development will not fight each other (Gartzke, 2007). Democracies may go to war with other democracies that are distantly located, culturally disparate and considerably poorer. Democracies or liberal societies that become poor, or fall behind other affluent nations because of the lack of growth or systemic changes such as the collapse of socialism may become aggressive; see Wenar and Milanovic (2009). What is also required for 
peace in a pair-wise dyadic sense between nations is not just democracy and economic inter-dependence, but also high levels of development (Hegre, 2000), as high income nations have most to lose from war with one another.

While the arguments described above mainly pertain to the issue of war between nation states, inferences about violent internal conflict can also be made. Economic stagnation, as in Africa between 1980 and 2000, or economic development that is very unevenly distributed can cause the tolerant niceties of an existing domestic social contract to become frayed. Those left behind and the under-privileged may revolt if adroitly organised. Equally, the relatively rich may choose to prey on the less fortunate, if they are no longer prepared to subsidise or support these groups. So-called democracies are not immune from these tendencies; they are not, however, the ideal polities as conceived by Kant or Rawls, and may therefore behave violently towards segments of their societies. Indeed, post-1991 developing countries are mostly characterised by imperfect democracies or anocracies; containing elements of democracy (multi-party electoral competition) along with some of the more invidious traits of autocracy (no effective checks on the executive, for example). It is also well known that stable autocracies and democracies are most likely to be at peace; the democratic transition maximizes the risk of conflict (Hegre et. Al, 2001). Ultimately, growth, increased economic interaction through globalization, as well as rising democratization are likely to promote peace between and within developing countries, mirroring Lipset's (1960) modernization hypothesis that democracy (and peace) inevitably follows economic growth. However, the path to modernization via the route of high globalization is fraught with the danger of different forms of conflict, and this is what I now turn to.

\section{$4 \quad$ Globalization and Inequality}

Increases in international trade brought about by globalization nearly always has distributional consequences. After an expansion of trade, the factors of production employed in the exportable sector will witness a rise in their relative remuneration. This is because the exportable sectors of the economy expand, and the importcompeting sectors contract, after increased international trade. Hence, globalization produces winners and losers. ${ }^{8}$ For example, with the end of the multi-fibre agreement 
which governed and restricted the import of garments from developing countries into OECD nations, the remaining European Union producers (in countries like Portugal) were hurt by Chinese goods, so they successfully lobbied for, and obtained a reimposition of import controls. The next question is whether or not society is in a position and prepared to compensate the losers from increased trade. Traditionally it was believed that if there was economic growth following enhanced trade, the gainers gain is greater than the loss of the losers; there is a potential for compensating the losers, provided enough political will exists to affect the re-distribution. Rodrik (2018) points out that when the barriers to international trade are already small, even further reductions in trade barriers lead to disproportionate losses in terms of jobs and/or real wages in import competing sectors that outweigh the 'gains' from trade in terms of cheaper import prices. In other words, further globalization in advanced stages of globalization leads to the additional welfare gains to consumers (cheaper imports) being swamped by the magnitude of job losses and wage contraction in the import competing sectors. There are also costs to the exchequer of social protection expenditures, and to the economy caused by some of those displaced workers exiting the official labour force.

Increased trade is not always the handmaiden of economic growth, although it has played an important part in historical economic development of the world's presentday affluent OECD economies. Trade may even hamper growth, if the trade is of an unequal nature. If there are increasing returns to scale or economies of scale ${ }^{9}$, freer trade may damage the growth prospects of smaller countries less able to take advantage of economies of scale. This means that the manufacturing sector in less competitive countries may contract or vanish after free trade is introduced; see Krugman (1981). The new economic geography literature (Krugman, 1991, for example) suggests the importance of agglomeration effects. Increased economic integration may cause greater clustering, particularly of manufacturing production, in certain regions, causing it to move away from certain existing areas that become peripheral. Obviously, welfare in these peripheries is adversely affected.

Financial globalization and open capital markets are regarded as less benign. They are believed to promote financial crises, particularly in developing countries. For example the recent crisis in the Southern European (Greece, Spain, Portugal) plus Ireland part 
of the euro-zone can be linked to capital mobility, a common lower interest rate leading to unsustainable financial flows and debt accumulation, which, once the financial boom was over, led to massive contractions in the economies of those countries.

In developing countries, Bussman and Schneider (2007) argue that policies aimed at greater globalization lead to internal conflict risk increasing outcomes, but highly open economies cannot sustain high levels of international trade and foreign direct investment inflows if they are in conflict. Indeed, they find some empirical evidence to support these findings in a cross sectional econometric investigation of conflict risk. This is particularly true if countries pursuing liberalization are at lower stages of economic development and have been unsuccessful in promoting economic growth in recent times.

Ted Gurr (1970) developed the notion of relative deprivation: when people perceive that they have less than what they regard as their just deserts they will revolt. This is more likely to occur when the general or average level of prosperity is increasing, but some groups are left behind as is often the case following globalization.

What about the policies that might mitigate the conflict enhancing effects of globalization? Rodrik (1998) pointed out that in general more open economies tended to have bigger governments. The larger size of government (relative to national income) is predicated on the need for the state to provide a form of insurance or social safety net against the temporary adverse economic shocks that tend to strike at more open economies with greater frequency. In a similar vein, Rodrik (1999) argued that one of the reasons for the decline in growth in many parts of the developing world was due to a decline in social cohesion. A more equitable and less conflict prone society is better able to withstand shocks and recover, as was shown by South Korea, for example, following the Asian financial crisis of 1997.

One of the greatest challenges of our day is the growing global tide of inequality which has coincided with increasing globalization, and what to do to redress this phenomenon. (Stiglitz, 2012; Piketty, 2014) ${ }^{10}$ with some exceptions in selected Latin 
American countries like Brazil. The chief misgivings with these developments are to do with the income and wealth share of the richest $1 \%$ or $10 \%$ of the population. .If we take a truly cosmopolitan view, treating the entire planet as a single entity, global inequality may have declined by about 2 percentage GINI points between 1988 and 2008 to around 70.5 (Lakner and Milanovic, 2015) as the two populous poor developing countries, China and India narrow their per-capita income gap with rich countries like the United States. The authors point out, however, that this finding may mask the serious underestimation of the income of the top decile in the income distribution, who are often missed out in household surveys. Accompanying this rise in inequality is more precarious work, informalisation and self-employment. ${ }^{11}$ In addition, the wealth share of the richest $1 \%$ in the world is greater than the rest of the population's (99\%) total wealth according to some sources (OXFAM, 2016). The present world's super-rich are considerably richer in real terms than the super-rich of the past like the Carnegie's and Rockefellers (Goda, 2014) ${ }^{12}$. In the developing world, recent surges in economic growth have lowered poverty, and even promoted a range of countries to middle income status, along with a doubling of people (about 3.2 billion) who are just above a decent global poverty line (\$2.5 to $\$ 10$ per-day in purchasing power parity dollars). But this vast swathe of the global citizenry occupy a precariously unstable zone and risk descending back to poverty (Sumner, 2016).

Globalization may or may not assist increased economic growth, but does the greater inequality that accompanies it hamper or promote growth? Classical and neoclassical growth theories emphasized the role of saving (invested in productive capacity), chiefly by the owners of capital, in generating growth. In this connection a greater degree of inequality may accompany initial growth spurts, as exemplified by the famous Kuznets (1955) hypothesis about the inverted U shaped relationship between income inequality and per-capita income. As growth accelerates, inequality first rises, but after reaching a certain peak in average income, inequality begins to decline. This pattern certainly explains the growth history of the earliest industrialized nations, such as the UK and the USA, as demonstrated by Kuznets (1955).

After the 1980s, however, inequality is widely regarded to be on the increase again in most advanced industrialized nations. Inequality can facilitate greater economic growth if capitalists are more innovative, and save a greater proportion of their 
income compared to other classes (Kaldor, 1957). But, this may not apply if the greater inequality is a result of the acquisition of a rent by the highest income earners, rather than returns from productive investment in manufacturing, as is the case for much of the financial investments of the wealthiest at present; see Orhangazi (2008) on financialization. Moreover, the Kuznets relationship does not seem to hold for the post-second world war growth experiences in East Asia (Alesina and Rodrik, 1994).In contrast with the theories of growth embodying exogenous technical progress, endogenous growth theories highlight the importance of human capital in promoting growth, thus implying the positive role of publically funded education. Easterly (2007) demonstrates that a higher middle class share of income does promote growth, because the middle classes traditionally clamour for more growth enhancing public goods, including publicly funded education and health care.

Dabla-Norris et. Al (2015) and Ostry, Berg and Tsangarides (2014) show that the recent growth experiences of a cross-section of developed and developing countries suggest that inequality is harmful to growth prospects. This could be because greater inequality leaves economies more prone to financial $\mathrm{crises}^{13}$, greater inequality results in less human capital accumulation, and because inequality contains within it the seeds of conflict, which is harmful for growth.

On the causes of recent rises in income inequality, Dabla-Norris et. Al (2015) point out that unskilled labour saving technical progress, financial globalisation (but not trade openness) and less regulation of labour markets, including the informalisation of work are the chief culprits. The nature of global manufacturing production has become increasingly fragmented, with components produced and shipped to different locations across the globe, turning nation states into regions.

Financial globalization, and the greater mobility of capital contributes to greater inequality by lowering the bargaining power of labour under the threat of economic activities locating overseas (Furceri, Loungani and Ostry, 2017). Rodrik (2018) also maintains that greater mobile capital shifts the burden of adjustment to economic shocks more to labour. Highly mobile international capital also has the effect of lowering corporate taxes via tax competition, and narrows the fiscal space and capacity of the state (see Rodrik, 2018 and references therein). Technical progress has 
been cited as a major cause of job destruction, the displacement of production line workers, and even the hollowing of the middle class. But as Rodrik (2018) points out, it is much more difficult to disentangle the effects of technical progress on real wages and employment from globalization effects causing the same movements.

In empirical models, redistributive policies, including social protection expenditures appear to no longer harm growth prospects (Ostry, Berg and Tsangarides, 2014) in recent years. Traditionally, it was believed that greater government consumption was negatively correlated with growth (Tavares and Wacziarg, 2001), because of crowding out effects and distortions to incentives. Thus, redistributive policies financed by taxation were distortion inducing, even when it resulted in greater equity and social justice. Economic efficiency and equity needed to be separated, and furthermore there was an efficiency-equity trade-off (see Okun, 1975), empirical evidence for which seems to have weakened in recent years, linked among other phenomenon to new forms of market failure.

Traditional arguments against excessive inequality were grounded in purely 'equity' considerations based on society's aversion to highly unequal outcomes. A modicum of unequal outcomes as a reward for differential effort, talent and risk taking can be regarded as fair, but what is both unjust and inefficient is inequality of opportunity (Roemer, 1998). ${ }^{14}$ This may be rooted in either systematic discrimination or unequal access to opportunities such as education. It can be argued that present day trends in the distribution of income with the accelerating share of the top $1 \%$ in the global income distribution do produce inequality of opportunity and hamper intergenerational mobility, particularly because much of the wealth of the wealthiest is principally attributable to a rent earned from speculative financial investments. In the ultimate analysis, in the presence of many market imperfections, adverse selection, substantial economic rents and inequality of opportunity, the separability between the efficiency and equity arguments against inequality fall apart, but above all make social protection and redistributive policies justifiable.

Where there is a distributive conflict between the haves and the have nots, a high degree of inequality may damage future growth prospects (Alesina and Rodrik, 1994), thus explaining the redistributive policies pursued after the Second World War in 
North-East Asia (particularly with regard to land redistribution)prior to their growth spurt, and the absence of a Kuznets relation there. As already indicated, Rodrik (1999) argues that social conflict measured by indicators such as inequality, unless managed by well-functioning institutions can lead to growth collapses. In other words, persistent inequality destabilises society and the social contract; this may produce social conflict, even if it is not full-blown armed conflict.

This leads us to the political economy considerations, as the choice and implementation of policies by the state are fundamentally the outcome of strategic interaction between different factions with different interests. The pressure for redistribution results in the initial democratic contract (Acemoglu and Robinson, 2009), with some power transferred to the less affluent, and consequently some redistribution. Downs' (1957) famous median voter theory suggests that the median voter's preferences prevail in a democracy. Meltzer and Richard (1981) suggest that increases in the size of government in democracies are due to median voter pressure for redistribution. This is either due to the extension of the franchise (which lowers the median voter's income relative to the national mean income), or when economic growth or transformation raises the average or mean income above that of the median voter, implying greater inequality.

Our present era, however, can be characterised by a decline in median voter power. The rise in inequality world-wide has mean that the average or mean income is rising faster than median income. ${ }^{15}$ There has been a considerable shift in political clout away from the median voter to the policies that suit the super-rich, who compel the formulation of national policies to suit the owners of internationally mobile capital and work skills. This manifests itself, chiefly, in the state feeling compelled to follow policies of fiscal austerity and wage compression, lest participation in the globalised economy is jeopardised. This also frays the domestic social contract, and leads to the diminution of social protection. By contrast during the era of limited globalization prior to the 1980s, the interests of the rich and the median income group did not necessarily clash; it was an era of growing social protection, the provision of public services like education and health, employment rights, declining inequality and consensual democracy. The recent phenomenon of hyper-globalization, in the words 
of Rodrik (2017), can lead to a democratic deficit and produce a backlash; this is what we turn to in the next section. ${ }^{16}$

\section{Illiberalism and Populism}

Since the expression 'illiberal democracy' was coined by Fareed Zakaria (1997), a host of scholars and commentators have drawn our attention to the recent rise of populist illiberalism and increased authoritarianism; for example, Rodrik (2017). The trend towards mainly right-wing populism is a feature mainly of developed countries that are established democracies; the authoritarian feature is mainly ascribable to developing countries. As Rodrik (2017) puts it, a liberal society is one where there is respect for minority rights, constraints on the executive (and legislature), with an independent judiciary, and there is respect for the rule of law. In a democracy there is an electoral process in place. A purely electoral process may elect populist dictators or parties with scant respect for liberalism. The tyranny of the majority may engender illiberal actions, as described by classical liberals (Mill, 1859; de Tocqueville, 1835). ${ }^{17}$ Additionally, populist leaders (referred to as demagogues in Aristotle's Politics) can cause the degeneration of the polity.

Rodrik (2018) points out that the rise in populism coincides with hyper-globalization. The vote share of populist parties since 2000 in selected European and Latin American nations has exceeded 10\% (Rodrik, 2018, figure 1). Even in other countries whose electoral system marginalizes fringe parties such as the United States, an arguably populist figure was elected as President in 2016, and the electorate in Britain voted to exit the European Union at the behest of populist messages. Hence, even in countries where the absence of proportional representation sidelines populist parties in legislatures, populist politicians can function in mainstream political parties. In Latin America, Venezuela for example, populism tends to be left-wing, harking back to the populist left-wing tradition of Peronism in the Argentina during the 1930s.

In Europe, by contrast, with the exception of Greece, Spain and Italy, most populist parties are right wing. Although the support group for populism includes those impoverished by globalization, or millennials (youth) whose economic prospects are bleaker than for their parent's generation, the phenomenon of mass migration in 
Europe has empowered right-wing demagogues who conflate the disadvantaging effects of hyper-globalization with immigration, especially Muslim immigrants (Rodrik, 2018). Murshed (2011) outlines a theoretical model where a fear message is sent out by a populist right-wing politician. The potential vote bank must interpret the signal for what it is. Those with a negative experience of migrants (Muslims, Africans), those who are older, and especially those with less education often cannot separate the noise from the signal, and subscribe to the negative message. For the UK, for example, Becker, Fetzer and Novy (2017) indicate that the Brexit vote was greater in electoral districts with greater economic disadvantage after controlling for age and education. The right-wing politician simply uses the anti-immigrant or Islamophobic stance as a ploy to get elected, but could have little intention of fundamentally rolling back the inequality that hyper-globalization has produced.

Indeed, it can be argued that it is no small coincidence that liberalism and democracy, as outlined above, co-exist (Rodrik, 2017). The majority can always tyrannize the minority in purely elective democracies. Mukand and Rodrik (2017) analyse a model in which society is fragmented along three lines: first there is a small elite who are characterised by their wealth, then a majority group that is poorer, and finally a minority who are differentiable from the majority by their different ethnicity. The minority could be immigrants. They use the model to distinguish between the rise of right-wing populism and left-wing populism. The former can be characterized by those that exploit cultural differences with the minority, and the latter by those that champion the cause of the relatively poorer. It may be that right-wing populism is more appealing to voters in societies experiencing greater immigration by those with different ethnicities and religion, and where the degree of social protection did not keep pace with the increase in inequality and marginalization due to policies of austerity. These members of the public conflate both economic and social problems with the influx of migrants, choosing to scapegoat them for nearly all of society's difficulties. The important point is that they are encouraged to think in this way by populist politicians and parties. Left-wing movements arise when the majority stand up to the elites

In developing countries there has been a rise in inequality, particularly in nations experiencing economic structural transformation. Associated with this, there has been 
a rise in authoritarian tendencies, even the rise allegedly authoritarian developmental states, who employ elections and plebiscites. The V-Dem project produces several indices of democracy; see V-Dem (2017). Their concept of liberal democracy combines the presence of electoral democracy with a rule of law that involves respect for civil liberties, and judicial, as well as legislative, constraints on executive power. In the period between 2011 and 2016, more countries experienced statistically significant declines in this index than did the number of countries which made progress in this respect. Most of both groups of countries were in the developing world. If one looks at only the liberal component of the liberal democracy concept (excluding the electoral process), then 10 countries have made an advance, whereas 13 countries have experienced a decline in the liberal component between 2006 and 2016. When looking at the participatory principle of democracy, it is noteworthy that there has been a rise in the use of plebiscites and referenda in recent years (Altman, 2017). This may, on the surface, appear as good news for democracy, but in reality this form of democracy is a tool utilized by authoritarian chief executives to override legislative and constitutional constraints on their exercise of power.

Mention should also be made of the third pillar of the liberal peace, common membership of international organizations (Gleditsch, 2008). This allows for the exercise of soft power to manage international tensions and various forms of interstate hostility. International organizations provide the perfect fora where disagreements can be negotiated on and bargained for without engaging in hostile gestures towards other nation states. The British referendum result to withdraw from the European Union, and earlier actions by the USA to withdraw from organizations like UNESCO, deal a body blow to the third liberal pillar.

\section{Conclusions}

The chances of the well-ordered tolerant societies envisaged by Rawls living in peace within themselves and with one another have greatly diminished with the rise in inequality, the growing wealth and income share of the richest $1-10 \%$ of the population and the rise in varieties of populism, as well as the accretion of autocratic tendencies in recent years. Also, the quality of Kant's foedus pacificum have been dealt a severe blow by nations such as the UK choosing to leave the European Union, 
adversely affecting the utilisation of soft power via common membership of international organisations. Neither of these developments means war, as is commonly understood, but it serves to enhance hostility between nations, and between social groups within a nation state and points to a diminution of the ideal form of the liberal peace described in section 2 .

We also may have come to the stage in a world where economic interactions such as the exchange of goods, provision of services and the movement of finance has become so highly internationalized that further increases in globalization cannot deliver greater prospects of peace, as outlined in section 3. But the logic of the capitalist peace still holds water; the intricate nature of the economic interdependence between advanced market economies, almost entirely rules out war, but other hostile attitudes can still persist, and even grow, given recent developments, including the rise in populist politics.

The growth in inequality, but more especially the creeping rise in the social mobility inhibiting inequality of opportunity, has spawned the illiberal backlash manifesting itself in the rise in mainly right wing populist politics. A large segment of immiserized voters vote for populists knowing that once elected the populist politician is unlikely to increase their economic welfare, as long as they create discomfiture for certain establishment circles, vis-à-vis whom these voters see themselves as relatively deprived. Immigrants, and immigration is scapegoated and made responsible for all economic disadvantage and social evils following the simplistic and simple minded message of right-wing demagogues. It has to be said, that left-wing populism, too, has emerged in many societies, mainly among educated millenarians whose economic prospects are often bleaker than those of their parents, and in developing country regions (Latin America) with a strong Peronist tradition.

In developing countries there has been a growth in autocratic tendencies, the liberal half of a liberal democracy, even when the other part of democracy, the electoral process is broadly respected. The use of plebiscites by strong men to garner greater power has been a frequently used tool. There is even talk of autocratic rulers delivering development and economic growth. But the logic of Lipset's (1960) 'modernization' hypothesis, which argues that democracy is demanded by society as 
it becomes affluent may still ring true, even if the process is non-linear, and other complex factors need to be taken into account.

Faced with these challenges, we need to abandon our former, 'Panglossian' faith in the ability of markets to do good even when it disadvantages the many. The rules of globalization and capitalism only serve elites who are owners of internationally mobile skills and wealth. Rodrik (2017) has pointed out the globalization trilemma, whereby the simultaneous achievement of national sovereignty, democracy and hyper-globalization is impossible. It is worth re-iterating that hyper-globalization refers to a situation where for the collective the pains from increased globalization in terms of adverse distributional consequences outweigh the gains in terms of enhanced income.

Rodrik (2018) points out that earlier on the advance of globalization was made relatively more acceptable in Europe compared to the United States, given the greater prevalence of social protection in the continent. Gradually, after 1980, and especially since the dawn of the new millennium more and more groups have been disadvantaged by globalization and labour saving technical progress, and the politics of austerity has diminished social protection, fraying pre-existing domestic social contracts, and social mobility has been greatly diminished. Thus many, like Rodrik (2017) advocate a more limited globalization, harking back to the halcyon days of the Bretton Woods era (1945-73). A retreat from hyper-globalization is desirable, but not through channels that diminish international cooperation and partnership, like Brexit and President Trump's protectionist sabre rattling that undermine agreements like NAFTA. What is needed is internationally coordinated checks on hyper-globalization and agreements on certain wealth taxes on the richest individuals, as well as job destroying automation. These policies are needed to address the alarming rise in wealth inequality, given the fact that social protection alone can only have a palliative, but not curative, impact on these inequalities. 


\section{REFERENCES}

Alesina, Alberto and Dani Rodrik (1994) Distributive Policies and Economic Growth, Quarterly Journal of Economics, 109(2): 465-490.

Altman, David (2017) 'The Potential of Direct Democracy: A Global Measure (19902014), Social Indicators Research, Issue 3/2017: 1-21.

Angell-Lane, Ralph Norman (1910) The Great Illusion: A Study of the Relation of Military Power in Nations to Their Economic and Social Advantage. London: Heinemann.

Aristotle. Politics. Oxford: Clarendon Press (1905)

Becker, Sascha, Thiemo Fetzer and Dennis Novy (2017) 'Who Voted for Brexit? A Comprehensive District-Level Analysis', Economic Policy, 32 (92): 601-650.

Bussman, Margit and Gerald Schneider (2007) 'When Globalization Discontent Turns Violent: Foreign Economic Liberalization and Internal War', International Studies Quarterly, 51 (1): 79-97.

Cobden, Richard (1835) 'Commerce is the Grand Panacea' reprinted in E K Bramsted and K J Melhish (eds) Western Liberalism: A History in Documents from Locke to Croce, London: Longman, 1978: 354-357.

Collier, Paul (2007). The Bottom Billion: Why the Poorest Countries are Failing and What Can be Done about it, Oxford: University Press.

Dabla-Norris, Era, Kalpana Kochkar, Nujin Suphaphiphat, Frantisek Ricka and Evridiki Tsounta (2015) Causes and Consequences of Income Inequality: A Global Perspective, IMF Staff Discussion Note.

De Tocqueville, Alexis $(1835,2000)$ Democracy in America, edited by Harvey C. Mansfield, and Delba Winthrop, Chicago: University of Chicago Press.

Downs, Anthony (1957) An Economic Theory of Democracy, New York: Harper and Row.

Dorussen, Han and Hugh Ward (2010) 'Trade Networks and the Kantian Peace', Journal of Peace Research, 47(1): 29-42.

Doyle, Michael W (1986) 'Liberalism and World Politics', American Political Science Review 80(4): 1151-69.

Easterly, William (2007) Inequality Does Cause Underdevelopment: Insights from a New Instrument, Journal of Development Economics, 84(2): 755-776.

Furceri, Davide, Prakash Loungani and Jonathan Ostry (2017) 'The aggregate and Distributional effects of Financial Globalization', mimeo, International Monetary Fund. 
Gartzke, Erik (2007) 'The Capitalist Peace', American Journal of Political Science 51(1): 166-191.

Gleditsch, Nils Petter (2008) 'The Liberal Moment Fifteen Years On', International Studies Quarterly 15 (4): 691-712.

Goda, Thomas (2014) Global trends in Absolute and Relative Wealth Concentrations,

CIEF Working Paper, 14-01-2014, ile:///C:/Users/ab2380/Downloads/SSRNid2395003.pdf, accessed $6^{\text {th }}$ March 2018.

Gurr, Ted R (1970) Why Men Rebel, Princeton: Princeton University Press.

Hegre, Håvard (2000) 'Development and the Liberal Peace: What Does It Take to Be a Trading State', Journal of Peace Research 37 (1): 5-30.

Hegre, Håvard; Tanja Ellingsen; Scott Gates; and Nils Petter Gleditsch (2001) 'Towards a Democratic Civil Peace? Democracy, Civil Change, and Civil War 18161992', American Political Science Review, 95, 17-33.

Human Security Report (2005) University of British Columbia, http://www.humansecurityreport.info/.

Kaldor, Nicholas (1957) A Model of Economic Growth, Economic Journal, 67 (268): 591-624.

Kant, Immanuel (1795) Perpetual Peace and Other Essays on Politics, History and Morals, reprinted 1983. Indianapolis: Hackett Publishing.

Krugman, Paul (1981) 'Trade, Accumulation and Uneven Development', Journal of Development Economics, 8: 149-61.

Krugman, Paul (1991) Geography and Trade, Cambridge MA: MIT Press.

Kuznets, Simon (1955) Economic Growth and Income Inequality, American Economic Review, 45 (1): 1-38.

Lakner, Christoph and Branko Milanovic (2015) Global Income Distribution: From the Fall of the Berlin Wall to the Great Recession, World Bank Economic Review, doi: 10.1093/wber/lhv039.

Lipset, Seymour (1960) Political Man: The Social Bases of Politics. New York: Doubleday.

Mamoon, Dawood and S Mansoob Murshed (2008) 'Unequal Skill Premiums and Trade Liberalization: Is Education the Missing Link?', Economics Letters, 100(2): 262-266. 
Meltzer, Allan and Scott Richard (1981) A Rational Theory of Government, Journal of Political Economy, 89(5): 914-927.

Mill, John Stuart (1859) On Liberty, London: Longman, Roberts and Green.

Mizruchi, Mark (2013) The Fracturing of the American Corporate Elite, Cambridge MA.: Harvard University Press.

Montesquieu, Charles-Louis de (1748) De l'Espirit des Lois, reprinted 1979. Paris: Flammarion.

Mukand, Sharun and Dani Rodrik (2017) The Political Economy of Liberal Democracy, mimeo, Harvard Kennedy School.

Murshed, S Mansoob (2010) Explaining Civil War: A Rational Choice Approach, Cheltenham: Edward Elgar.

Murshed, S. Mansoob (2011) 'The Clash of Civilizations and the Interaction between Fear and Hatred', International Area Studies Review 14 (1): 31- 48.

Murshed, S Mansoob and Dawood Mamoon (2010) 'Not Loving Thy Neighbour as Thyself: The Trade, Democracy and Military Expenditure Explanations behind IndiaPakistan Rivalry', Journal of Peace Research.

Okun, Arthur (1975) Equality and Efficiency: the Big Trade-Off, Washington: Brookings Press.

Orhangazi, Ozgur (2008) Financialization and Capital Accumulation in the Nonfinancial Corporate Sector: A Theoretical and Empirical Investigation on the US Economy, 1973-2003,Cambridge Journal of Economics, 32(6): 863-886.

Ostry, Jonathan, Andrew Berg and Charalambos Tsangarides (2014) Redistribution, Inequality and Growth, IMF Staff Discussion Note.

OXFAM (2016) Wealth: Having it All and Wanting More, https://www.oxfam.org/sites/www.oxfam.org/files/file_attachments/ib-wealth-havingall-wanting-more-190115-en.pdf, accessed 23 ${ }^{\text {rd }}$ January 2016.

Paine, Thomas $(1791,1792)$ The Rights of Man, Reprinted in 1995 as Rights of Man, Common Sense and other Political writings, edited by Mark Philip. Oxford: Classics.

Piketty, Thomas (2014) Capital in the Twenty-first Century, Cambridge, Massachusetts: Harvard University Press.

Polachek, Solomon W (1997) 'Why Democracies Cooperate More and Fight Less: The Relationship Between International trade and Cooperation', Review of International Economics 5(3): 295-309.

Rawls, John (1999) The Law of Peoples, Cambridge, MA: Harvard University Press. 
Rodrik, Dani (1998) 'Why do More Open Countries Have Bigger Government', Journal of Political Economy, 106(5): 997-1032.

Rodrik, Dani (1999) 'Where Did All the Growth Go? External Shocks, Social Conflict, and Growth Collapses', Journal of Economic Growth, 4 (4): 385-412.

Rodrik, Dani (2017) Straight Talk on Trade: Ideas for a Sane World Economy, Princeton: University Press.

Rodrik, Dani (2018) 'Populism and the Economics of Globalization', Journal of International Business Policy, https://doi.org/10.1057/s42214-018-0001-4.

Russett, Bruce, and John Oneal (2001) Triangulating Peace: Democracy Interdependence and International Organizations. New York: Norton.

Standing, Guy (2011). The Precariat: The New Dangerous Class. London: Bloomsbury Academic

Stiglitz, Joseph (2012) The Price of Inequality: How Today's Divided Society Endangers Our Future, New York: Norton.

Sumner, Andy (2016) Global Poverty: Deprivation, Distribution, and Development since the Cold War, Oxford: University Press.

Tavares, Jose and Romain Wacziarg (2001) 'How Democracy Affects Growth', European Economic Review, 45 (8): 1341-1378.

V-Dem Institute, Varieties of Democracy (2017), Annual Report, https://www.vdem.net/en/news-publications/annual-report/, accessed $9^{\text {th }}$ March 2018.

Wenar, Leif and Branko Milanovic (2009) 'Are Liberal Peoples Peaceful?', Journal of Political Philosophy, 17 (4): 462-86.

Zakaria, Fareed (1997) 'The Rise of Illiberal Democracy', Foreign Affairs, 76(6): 22 43.

Biography: Syed Mansoob MURSHED is Professor of Economics at Coventry University in the UK, and is also Professor of the Economics of Conflict and Peace at the International Institute of Social Studies (ISS) of the Erasmus University of Rotterdam (EUR) in the Netherlands. He was the first holder of the rotating Prince Claus Chair in Development and Equity in 2003. He was a Research Fellow at UNU/WIDER in Helsinki where he ran Projects on Globalization and Vulnerable Economies and Why Some Countries Avoid Conflict, While Others Fail. At the ISS he was responsible for a Dutch Scientific Council (NWO) project on Managing Extractive Natural Resources in Bolivia and Ecuador. He also ran a project on The Two Economies of Ireland, financed by the International Fund for Ireland at the Northern Ireland Economic Research Centre (NIERC), Belfast. He is currently working on a project linking food insecurity to domestic conflict. He is the author of seven books and some 150 book chapters and journal articles. His research interests are in the economics of conflict, aid conditionality, political economy, macroeconomics and international economics.

\footnotetext{
${ }^{1}$ Realist political science, however, maintains that commerce does not produce peace per se, although war disrupts trade.

${ }^{2}$ Although, as Rodrik (2018) argues there are left-wing populist tendencies in Latin America.
} 
${ }^{3}$ Sections 2 and 3 are closely related to my earlier work on the liberal peace; see Murshed (2010, chapter 7), for example.

${ }^{4}$ Akin to Thomas Hobbes' conception of the non-contractual 'state of nature'.

${ }^{5}$ This could also create a confederation of nations with common values, such as with the European Union's acquis communautaire.

${ }^{6}$ Even if the war on terror is justified, its conduct is often unjust.

${ }^{7}$ For example, the Wall Street crash of October 1929 heralded the world-wide Great Depression of the 1930s; the effects of the flawed regulation of US sub-prime lending markets have produced global fallout.

${ }^{8}$ In developing countries (mainly in Asia) that have experienced an increase in their export of unskilled labour intensive goods (mainly garments) one would expect a rise in the remuneration of the unskilled relative to the skilled. But this has not happened because of the shortage of skilled personnel (less public education expenditure) and the huge numbers of unskilled workers coming from the hinterland; see Mamoon and Murshed (2008).

${ }^{9}$ This means that if inputs are doubled output is more than doubled, implying falling unit costs of production, and greater competitiveness.

${ }^{10}$ According to Piketty (2014), the alarming trend in inequality mainly stems from wealth inequality, as well as the income share of top groups relative to poorest groups. There is a tendency for the wealth to national income ratios to increase since the 1970s, having declined for a period prior to that; wealth, whose ownership is more concentrated than income, multiplies faster than wage income creating an ever widening gap between capital and labour, the biggest source of inequality.

11 This the notion of a new vulnerable social class with low human, financial and social capital endowments making their livelihoods precarious; see Standing (2011)

12 There is a much greater concentration of wealth at the top nowadays.

${ }^{13}$ This is because the extremely wealthy demand a high return to their financial investments, and the financial debt burden of the relatively poor, if securitized, can make economies more prone to financial crises, which in turn can cause major recessions.

${ }^{14}$ This refers to severe limitations on the prospects of social mobility based on either ethnicity, religion or membership of disadvantaged socio-economic groups.

${ }^{15}$ Rodrik (2017) cites the work of Mizruchi (2017) who argued that in the early post-war era (1945 to the 1970s) the corporate elite in the United States exhibited ethical considerations of civic responsibility and enlightened self-interest.

${ }^{16}$ Rodrik (2018) defines hyper-globalization to occur when the political and distributive costs of increased globalization are in excess of the economic benefits.

${ }^{17}$ Arguably, the early constitution design of the United States with its checks and balances, separation of powers, as well as a bill of rights was designed to prevent such outcomes. 